\title{
Risk factors for dirty dairy cows in Norwegian freestall systems
}

\author{
L. E. Ruud, ${ }^{* 1}$ K. E. Bøe, ${ }^{*}$ and O. Østerås† \\ *Department of Animal and Aquacultural Sciences, Norwegian University of Life Sciences, N-1432 Ås, Norway \\ †Department of Production Animal Clinical Sciences, Norwegian School of Veterinary Science, N-0033 Oslo, Norway
}

\section{ABSTRACT}

Cow cleanliness is important for ensuring hygienic milk production and the well-being of dairy cows. The aim of this cross-sectional field study was to describe cow cleanliness in freestall-housed dairy herds and to examine risk factors related to thigh cleanliness. Cow cleanliness $(\mathrm{n}=2,335)$, management-related variables (e.g., ventilation and use of sawdust-bedded stalls), and housing-related variables (e.g., freestall design and number of cows per stall) were recorded in 232 Norwegian freestall-housed dairy herds. Cleanliness was scored on a 4-point scale ranging from clean (1) to very dirty (4). The cows were relatively clean on the udder and belly, dirtier on thigh and the rear part of the body, and dirtiest on the legs, with cleanliness scores (mean $\pm \mathrm{SD})$ of $1.64 \pm 0.62,1.62 \pm 0.65,2.02 \pm 0.75,1.77 \pm$ 0.58 , and $2.30 \pm 0.59$, respectively. With dirty thighs as the response variable, several variables were tested in a logistic regression mixed model and with repeated measurements within herd and cow. A high number of cows per freestall [odds ratio $(\mathrm{OR})=3.45$ ], no use of sawdust as bedding $(\mathrm{OR}=3.24)$ versus use of sawdust, and a low-positioned $(<0.85 \mathrm{~m}$ above stall floor) upper head rail "enclosing" the front of the stall $(\mathrm{OR}=1.42$ to 2.13 ) versus a position $>0.85 \mathrm{~m}$ were all risk factors for dirty thighs on the cows. Furthermore, liquid manure (score 2) versus more consistent manure (score $1 ; \mathrm{OR}=1.66$ ) and less tame cows (score 2 ) versus tame cows (score 1) were associated with an increased risk of dirty thighs $(\mathrm{OR}=1.24)$. The cleanest cows were associated with indoor temperatures in the range from 10 to $15^{\circ} \mathrm{C}$. For each 10-percentage-unit increase in relative air humidity, the risk of dirty thighs increased $(\mathrm{OR}=1.32)$. Freestalls with a construction hindering normal lying, rising, and standing movements should be avoided. Furthermore, focus is needed on indoor climate and manure consistency to obtain cows with clean thighs.

Key words: cow cleanliness, thigh cleanliness, freestall

Received April 7, 2010.

Accepted July 16, 2010.

${ }^{1}$ Corresponding author: lars.erik.ruud@tine.no

\section{INTRODUCTION}

The cleanliness of the cows is important for obtaining hygienic milk production, ensuring the well-being of the cows, and sustaining udder health in the herd (Schreiner and Ruegg, 2003; Munoz et al., 2008; Breen et al., 2009). The degree of cleanliness of the cow influences thermoregulation and hygiene at the time of slaughter: the dirtier the cow the greater the heat loss and the greater the danger to hygiene in the abattoir. The legs, belly, and thighs are usually the most contaminated body parts of animals housed in freestalls, whereas udders are normally cleaner because of being cleaned daily in connection with milking (Veissier et al., 2004; Reneau et al., 2005).

Methods for assessing cow cleanliness include some kind of subjective assignment into categories according to predefined criteria (Schreiner and Ruegg, 2003). Some studies used simplified methods assessing animal cleanliness if at least a given area of the body was contaminated (Hultgren and Bergsten, 2001), whereas others used a more fine-tuned scale; for example, from clean to very dirty (Schreiner and Ruegg, 2003; Gygax et al., 2007). Body parts (e.g., leg, thigh, and udder) are normally recorded separately. Interestingly, the original basis for the invention of the freestall was the problem of cleanliness (Bramley, 1962), and Schmisseur et al. (1966) confirmed that freestall housing kept cows cleaner and reduced bedding requirements compared with traditional loose housing. Between farms with similar systems, variation exists in cow cleanliness because of differences in housing design and management. In a survey by Veissier et al. (2004), a higher number of cows per stall tended to be associated with the cows being dirtier. Udder cleanliness, assessed as teat-end bacterial count, was worse if the stall was dirty (Zdanowicz et al., 2004). Regarding stall design, the length and width of the stall, together with the position of neck and head rails, were important for freestall cleanliness (Tucker et al., 2005; Fregonesi et al., 2009). Previous findings show that properties of the lying surface, as well as use of bedding, influence cattle cleanliness (Herlin, 1997; Fulwider et al., 2007; Norring et al., 2008). A dirty alley may lead to contamination of the cows as manure can be splashed directly on to the animals 
or can be transported into the stalls on the claws of cows (L. E. Ruud; unpublished data). Magnusson et al. (2008) found an association between the amount of manure in the alley and cleanliness of the udder and teats, where the frequency of scraping was important for cow cleanliness. Knowledge on the effects of tameness on cow cleanliness seems scarce. Kilgour (1975), in an open-field test where the cows were classified for temperament by the milker, claimed that easily scared cows urinated and defecated more frequently. The associations between test variables in this type of test are often difficult to interpret, and the direct link to manure consistency was not an objective of the study. Despite these problems, an open-field test is a useful measure of responses to fear or stress (Waiblinger et al., 2003). Furthermore, the dirtiness of the animals is usually considered a long-term effect of housing and management. Thus, factors such as the barn layout, indoor climate, feeding regimen, the management itself, and access to mechanical brushes may influence cattle cleanliness. The objective was to describe cow cleanliness in Norwegian freestall-housed dairy herds and to examine risk factors regarding housing and management variables associated with cow cleanliness.

\section{MATERIALS AND METHODS}

\section{The Herds}

This study was part of a larger descriptive and crosssectional project on freestall housing, in which the selection of herds concerned the entire project. From a questionnaire to all dairy consultants in Norway, we obtained a list of 2,400 dairy herds that were presumed housed in freestalls. All these farmers received a questionnaire covering several aspects of their freestall housing system; for example, age of the housing system, loose housing, or tie stalls. To be included in the study, the farmers had to fulfill the inclusion criteria: volunteering to participate, barns built 1995 to 2005, and herd size $>20$ standardized cow-years based on the year 2005 (cow-year $=$ sum of number of days within a herd from first calving to culling within $1 \mathrm{yr}$, divided by 365 ; this corresponded to mean number of cows in the herd at any time). All farms with robotic milking $(\mathrm{n}=44)$, with solid concrete floors $(\mathrm{n}=80)$ or solid rubber floors $(\mathrm{n}=16)$ in the alleys were included. From the initial phase of the freestall project, the distribution of floor types in the alleyways was approximately $80 \%$ slatted concrete floors, $18 \%$ solid concrete floors, and $2 \%$ solid rubber floors. Herds on slatted floors fulfilling the inclusion criteria were included only if they were located in the same municipality as farms with robotic milking or solid floors mentioned above. Hence, herds on solid concrete floors or rubber in the alleys were overrepresented compared with the total population. Therefore, this study is not a random study, but a cross-sectional descriptive study with random selection within groups (e.g., cows and stalls). The total material used consisted of 232 freestall-housed dairy herds located all over Norway.

\section{Cleanliness Observations}

During the indoor feeding period from September 2006 until May 2007, 232 herds were visited once by 1 of 5 trained observers, and several housing- and management-related variables were recorded. To standardize the data collection, an initial 2-d training session followed by 3 additional training sessions during the recording period was performed. Two of the observers conducted the majority of the assessments (73\%) and had regular meetings between farm visits to enhance the consistency in data recording. A systematic protocol was used to record data on each farm. Additionally, data were analyzed for significant clustering effects of observer to ensure no significant differences in recording. On each farm, 10 cows were subjected to cleanliness observations. According to their unique ID number, the cows were randomly chosen by selecting every second, third, et cetera, cow, depending on the herd size (n cows/10 and then closest integer). Cow cleanliness was scored for 2,335 cows in the 232 herds following a scheme adapted from Schreiner and Ruegg (2003) by using a 4 -point scale: $1=$ clean, $2=$ some dirt, $3=$ dirty, or $4=$ very dirty with caked-on dirt. Udder, belly, leg, thigh, and rear were assessed separately for cleanliness (Figure 1). Mean total cleanliness score was calculated per cow by adding together the scores for the different body parts; hence, a score of 5 indicated a totally clean cow and a score of 20 indicated a cow totally covered in dirt. Only risk factors for dirty thighs (for both the left and the right side) were analyzed in a full statistical model and reported in this paper. This was decided after checking the output, as cleanliness score for thigh was most correlated to the cleanliness score for the other body parts (Table 1). Thigh cleanliness described total cow cleanliness to a certain degree. Furthermore, dirty thighs (score 2 to 4 ) were most prevalent, after dirty legs. Magnusson et al. (2008) showed that leg cleanliness was more associated with flooring in the alley rather than other housing variables.

\section{Fixed Factors}

For each farm, 50 relevant housing and management variables (Table 2) were recorded and tested in the 
Table 1. Correlation between cleanliness observations based on the body parts: leg, thigh, udder, belly, and the rear part of the body for cows $(\mathrm{n}=2,335)$ in 232 Norwegian freestall-housed dairy herds

\begin{tabular}{lcccc}
\hline & Rear & Thigh & Leg & Udder \\
\hline Thigh $^{1}$ & 0.39 & & & \\
Leg $^{1}$ & 0.27 & 0.46 & & \\
Udder $^{1}$ & 0.32 & 0.45 & 0.34 & 0.37 \\
Belly $^{1}$ & 0.24 & 0.45 & 0.38 & \\
\hline
\end{tabular}

${ }^{1} P$-values for all correlations in the matrix $<0.001$.

statistical model. Only the most relevant variables are described in detail here.

Freestall Design. The variables recorded were freestall length and width, neck and head rail positions, rear curb height, brisket board height and location (brisket board found in $n=59$ herds), slope of stall base against rear curb, and freestall base softness (scored as concrete, rubber, mattress, or mixed floorings).

Barn Layout and Cow Density. Barn layout was recorded as number of freestall rows and number of dead-end alleys (alley length $>2 \mathrm{~m}$ and narrower than $3 \mathrm{~m}$ ). In addition, the numbers of cows and stalls in the main group of milking cows were recorded.
Climate. Relative air humidity (RH) and air temperature $\left({ }^{\circ} \mathrm{C}\right)$ were measured $1.5 \mathrm{~m}$ above the floor at the center of the feed bunk using a digital hygrometer (Kimo HD 100, Kimo Instruments, Montpon, France; www.kimo.fr).

Manure Consistency. Manure consistency, adapted from Hughes (2001) and Hulsen (2005), in the alleys was assessed by the observers slowly walking in the alley: $1=$ dry, not smeared cow pats, $2=$ dung smeared, but the observer's boot print remains distinct, $3=$ dung smeared and flat, and the observer's boot print disappears, and $4=$ liquid pools of feces ("water like").

\begin{tabular}{|c|c|c|c|c|}
\hline $\begin{array}{l}\text { Cow cleanliness } \\
\text { score }\end{array}$ & 1 (clean) & 2 (some dirt) & 3 (dirty) & 4 (very dirty) \\
\hline Rear & & & & \\
\hline Thigh & & & & \\
\hline Leg & & & & \\
\hline Udder & & & & \\
\hline Belly & & & & \\
\hline
\end{tabular}

Figure 1. Scheme for cow cleanliness scoring on the rear, thigh, leg, udder, and belly, where $1=$ clean, $2=$ some dirt, $3=$ dirty, and $4=$ very dirty. 
Management Factors and Cow Tameness. Number of brushes (mechanical, nonmechanical, or no brushes) in the main group of milking cows, as well as type (sawdust, straw, sand, turf, or no bedding) and amount of bedding were recorded. The amount (volume) of bedding in the $1.2 \mathrm{~m}$ closest to the rear curb of the stall was recorded by gently removing the bedding material into a 5-L container with a liter scale. Cow tameness (adapted from Waiblinger et al., 2003) was assessed in a simple avoidance test where the technician slowly (approximately 0.5 step per second) approached the same animals as those being assessed for cleanliness: $1=$ touchable cow that does not move away; $2=$ barely touchable with fingertips; $3=$ stays out of reach, but within 2 to $3 \mathrm{~m} ; 4=$ stays far away, $>3 \mathrm{~m}$.

\section{Statistical Analysis}

When making a model with many independent variables, one problem is how to reduce the number of

Table 2. Housing and management related variables evaluated before running the full statistical model

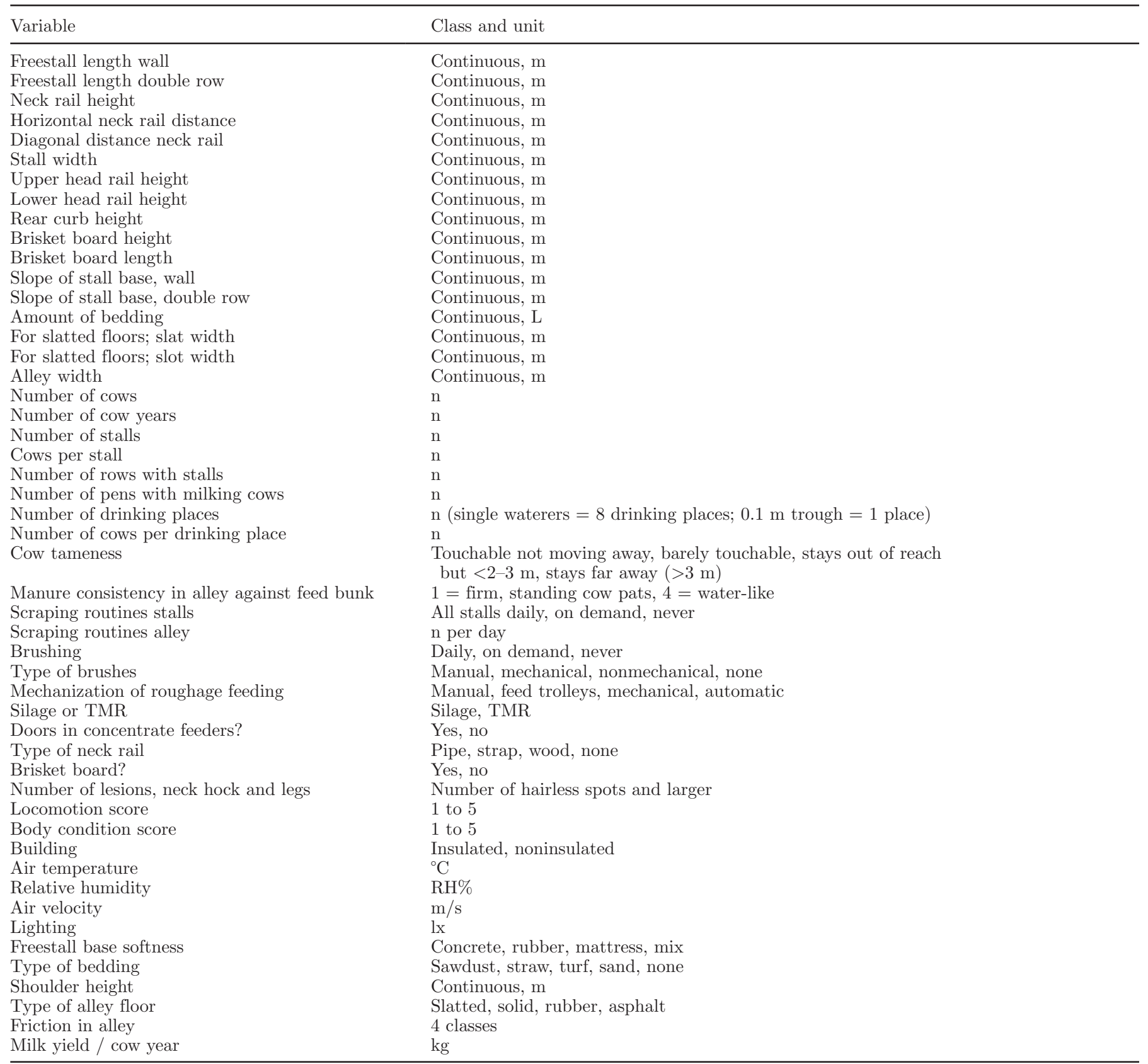


Table 3. Distribution of contamination (\%) on legs, thighs, rear, udder, and belly of dairy cows $(\mathrm{n}=2,335)$ in 232 Norwegian freestall-housed dairy herds

\begin{tabular}{|c|c|c|c|c|}
\hline \multirow[b]{2}{*}{ Contamination, $\%$} & \multicolumn{4}{|c|}{ Contamination score } \\
\hline & Clean (1) & $\begin{array}{c}\text { Some } \\
\text { dirt (2) }\end{array}$ & Dirty (3) & $\begin{array}{c}\text { Very } \\
\text { dirty (4) }\end{array}$ \\
\hline $\operatorname{Leg}^{1}$ & 6.3 & 72.1 & 18.7 & 2.9 \\
\hline Thigh $^{1}$ & 35.1 & 48.1 & 14.0 & 2.8 \\
\hline Rear $^{2}$ & 30.6 & 62.3 & 6.7 & 0.4 \\
\hline Udder $^{1}$ & 56.8 & 38.5 & 4.4 & 0.3 \\
\hline Belly $^{1}$ & 59.5 & 35.3 & 4.2 & 1.0 \\
\hline
\end{tabular}

${ }^{1}$ Based on individual mean value for evaluation on both sides of the body.

${ }^{2}$ One observation per cow.

descriptive variables to a number that will work in a regression model. Regardless of how this is performed, one loses potentially useful explanation variables in the final model. Fifty variables of interest remained after removing variables without interest logically or biologically, such as width of feeding alley and claw care routines. To reduce this number in the final model, all variables were first tested against thigh cleanliness score using PROC CORR in SAS (SAS version 9.1; SAS Institute Inc., Cary, NC). According to the principle of Bonferroni, only variables with $P$-value $\leq 0.001$ ( $P$-value of $0.05 / \mathrm{n}$ factors) in the correlation outcome were used, being introduced one by one into the final model using a forward stepwise procedure, and ranked according to degree of correlation with thigh cleanliness. Continuous factors were categorized by using the quartiles and 10 and 90 percentile groups. The final model was constructed with thigh as the statistical unit using PROC GENMOD (SAS version 9.1. from SAS Institute Inc.), with log link function, binomial distribution with clean (cleanliness score 1) or dirty (cleanliness score 2 to 4) as dependent variables. The regression was performed using alternating logistic regression according to Carey et al. (1993), and taking care of the correlated and repeated observation of thigh cleanliness within herd and cow by including cow as a subcluster nested within herd as subject in the repeated effect statement applying the logor option. For each introduction of a new variable, the results were checked for possible confounding and correlation between fixed effect variables already introduced. Variables with $P$-values $>0.05$ were excluded from the model. The goodness of fit was evaluated using delta deviance. The general model used for estimating $\beta$ was

$$
\begin{aligned}
\operatorname{Logit}\left(p_{i}\right) & =\beta_{0}+\beta_{1} x_{1 i c}+\ldots+\beta_{k} x_{k i c} \\
& +\mathrm{z}_{h e r d(i)}+\mathrm{z}_{\operatorname{cow}(c)},
\end{aligned}
$$

where $\beta_{0}$ is the intercept, $\beta_{1} x_{1 i c}+\ldots+\beta_{k} x_{k i c}$ are fixed effects, and $\mathrm{z}_{\text {herd(i) }}+\mathrm{z}_{\operatorname{cow}(c)}$ are random effects due to herd and cow. $\beta_{1}$ to $\beta_{k}$ are regression coefficients corresponding to the independent explanatory variables $x_{1}$ to $x_{k}$. Clustering effect due to observer was checked by testing observer as a random effect in the model.

\section{RESULTS}

\section{Herd Characteristics}

The average herd size for the farms visited was 38.6 \pm 14.6 (mean $\pm \mathrm{SD}$ ) cow-years with a range of 17.6 to 103.1. Norwegian Red dairy breed was the main breed (98.8\%). The shoulder height, measured at third thoracic vertebra, was $1.34 \pm 0.04 \mathrm{~m}$ with a range from 1.19 to $1.50 \mathrm{~m}$. Milk yield per cow year for the herds visited was $7,062 \pm 945 \mathrm{~kg}$, ranging from 3,224 to 9,249 $\mathrm{kg}$. All herds except 2 had only 1 group of milking cows.

\section{Cow Cleanliness}

The percentages of body parts scored as clean (1) were approximately $60 \%$ on both belly and udder, 35 and $31 \%$ on thigh and rear, respectively, and only $6 \%$ on legs (Table 3). A very low proportion of the cows scored very dirty (4). Mean cleanliness scores, assuming a continuous scale, were $2.30 \pm 0.59$ for legs, $2.02 \pm$ 0.75 for thighs, $1.77 \pm 0.58$ for the rear, $1.64 \pm 0.62$ for udder, and $1.62 \pm 0.65$ for the belly. Wide variation existed between herds in cleanliness (Figure 2). The total cleanliness score was $8.73 \pm 2.10$, ranging from 5 to 19 . In total, 31 cows $(1.3 \%)$ had a total cleanliness score of 5 (meaning totally clean), 1,874 cows $(80.3 \%)$ had a score $\leq 10$, and 2,288 cows $(98.0 \%)$ had $\leq 15$.

\section{Housing and Management Variables}

There were $42.3 \pm 16.8$ stalls in the herds, averaging $0.93 \pm 0.14$ cows per stall. Floors in the alley in the selected 232 farms were $57.3 \%$ slatted concrete floors, $34.5 \%$ solid concrete floors, and $6.9 \%$ solid rubber 

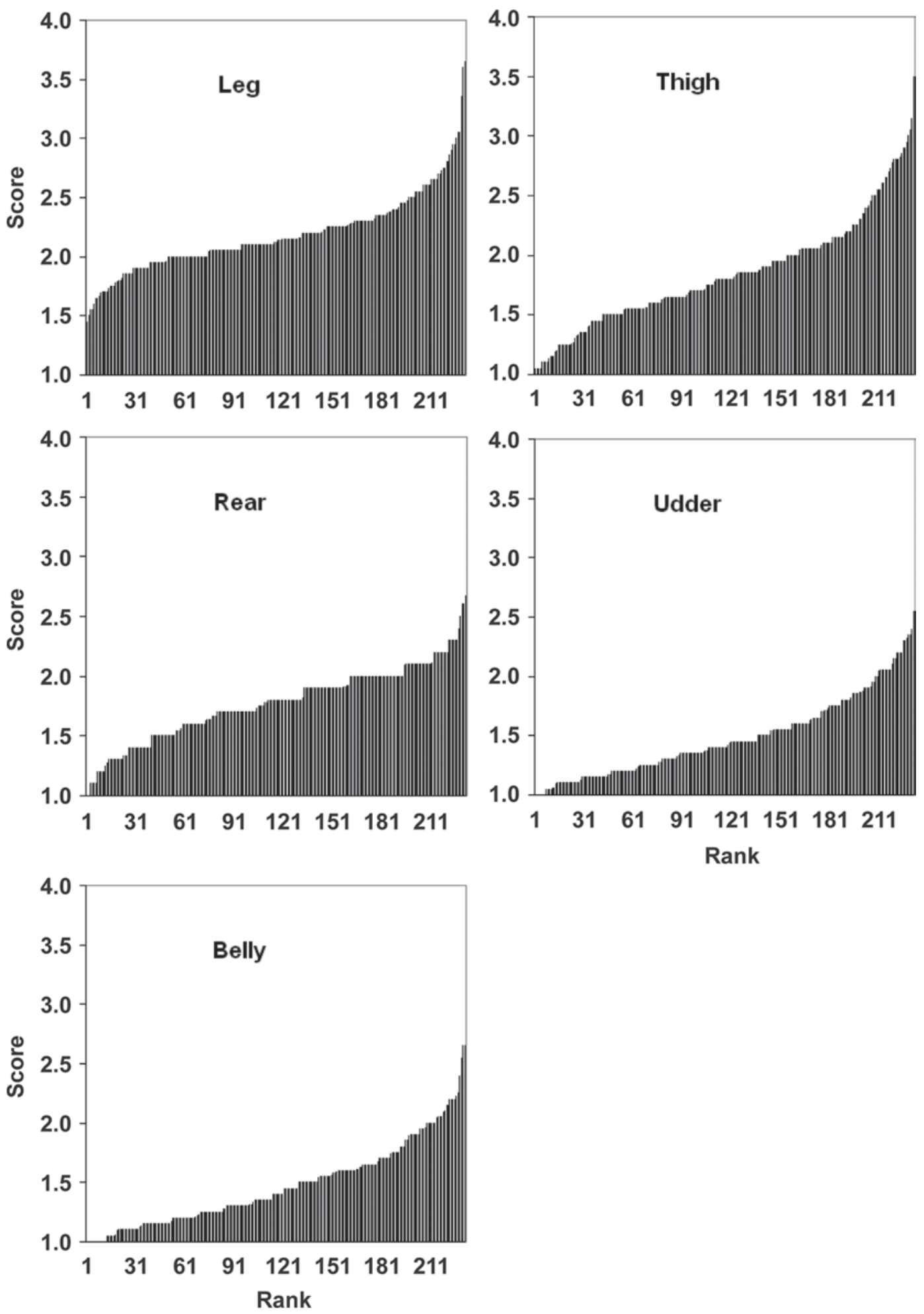

Figure 2. Mean cleanliness score (y-axis) for each herd for the body parts: leg, thigh, udder, belly, and the rear part of the body. Each body part was scored from 1 (clean) to 4 (very dirty). The illustration is at herd level and is based on observations for 2,335 cows in 232 Norwegian freestall-housed dairy herds ranked according to increasing cleanliness score (x-axis). 
Table 4. Estimated $\beta$ with SE, odds ratios (OR), and $95 \%$ CI for significant housing variables in a logistic model with binomial distribution ${ }^{1}$ for contamination caused by manure recorded on thighs in 232 Norwegian dairy herds

\begin{tabular}{|c|c|c|c|c|c|c|c|}
\hline Variable & Class & Herds, ${ }^{2} \mathrm{n}$ & Estimate & $\mathrm{SE}$ & OR & $95 \% \mathrm{CI}^{3}$ & $P$-value \\
\hline Intercept & & 232 & -2.191 & 0.841 & - & - & $<0.01$ \\
\hline \multirow[t]{2}{*}{ Sawdust } & No & 31 & 1.175 & 0.248 & 3.24 & $1.99-5.27$ & $<0.001$ \\
\hline & Yes & 201 & 0 & 0 & 1.00 & 1.00 & - \\
\hline Indoor temperature & & 232 & -0.227 & 0.049 & 0.80 & $0.72-0.88$ & $<0.001$ \\
\hline Indoor temperature & & 232 & 0.006 & 0.002 & 1.01 & $1.003-1.01$ & $<0.001$ \\
\hline Manure consistency & & 232 & 0.506 & 0.123 & 1.66 & $1.29-2.13$ & $<0.001$ \\
\hline $\begin{array}{l}\text { Indoor air humidity } \\
\text { (relative humidity) }\end{array}$ & & 232 & 0.028 & 0.008 & 1.03 & $1.01-1.04$ & $<0.001$ \\
\hline \multirow[t]{4}{*}{ Upper head rail height } & No rail & 41 & 0.148 & 0.186 & 1.16 & $0.81-1.67$ & 0.43 \\
\hline & $0.52-0.75$ & 43 & 0.758 & 0.220 & 2.13 & $1.39-3.28$ & $<0.001$ \\
\hline & $0.76-0.85$ & 38 & 0.352 & 0.204 & 1.42 & $0.95-2.12$ & 0.085 \\
\hline & $0.86-1.18$ & 110 & 0 & 0 & 1.00 & 1.00 & - \\
\hline \multirow[t]{3}{*}{ Tameness } & 1 (tame) & $1,014^{4}$ & 0 & 0 & 1.00 & 1.00 & - \\
\hline & 2 & $902^{4}$ & 0.215 & 0.082 & 1.24 & $1.05-1.46$ & $<0.01$ \\
\hline & 3 and 4 (avoidant) & $364^{4}$ & -0.116 & 0.326 & 0.89 & $0.47-1.69$ & 0.722 \\
\hline Cows per stall & & 232 & 1.239 & 0.500 & 3.45 & $1.29-9.20$ & $<0.02$ \\
\hline Cluster effect (herd) & & & 1.948 & 0.118 & 7.01 & $5.56-8.84$ & $<0.001$ \\
\hline Cluster effect (cow) & & & 0.690 & 0.089 & 1.99 & $1.67-2.38$ & $<0.001$ \\
\hline
\end{tabular}

${ }^{1}$ Clean or contaminated (1 vs. 2,3 , or 4$)$.

${ }^{2}$ The statistical unit used in the model is $\mathrm{n}=4,670$ thighs, and it is based on 2,335 cows registered in 232 dairy herds.

${ }^{3} 95 \%$ CI for OR.

${ }^{4}$ The number in the cell is the number of cows. Tameness observations are missing for 55 cows.

floors. For slatted floors, slot and slat width were 140.0 $\pm 13.6 \mathrm{~mm}$ and $39.5 \pm 3.2 \mathrm{~mm}$, respectively. Manure with consistency grade 1 or 2 was found in $68.5 \%$ of the herds, whereas water-like manure (grade 4) was found in $1.4 \%$. Relative humidity was $71.3 \pm 11.5 \%$ and indoor temperature $13.1 \pm 4.2^{\circ} \mathrm{C}$. In the tameness test, $85.1 \%$ of the tested animals were score 1 or 2 , indicating tame animals. In $39.7 \%$ of the herds, mechanical brushes were found; $32.7 \%$ had nonmechanical brushes, and no brushes were available for the cows in the remaining herds.

\section{Effect of the Housing Variables on Thigh Cleanliness}

Associations of significant housing variables with thigh cleanliness are in Table 4 . Of the variables selected, the number of cows per stall showed the highest association with thigh cleanliness, where more cows per stall meant dirtier thighs [odds ratio $(\mathbf{O R})=3.45$ ]. In herds not using sawdust as bedding in the freestalls, there was a higher risk $(\mathrm{OR}=3.24)$ of finding cows with dirty thighs compared with herds that were using sawdust. Upper head rails positioned from 0.52 to 0.75 $\mathrm{m}(\mathrm{OR}=2.13)$ or 0.76 to $0.85 \mathrm{~m}(\mathrm{OR}=1.42)$ above the freestall base were associated with dirtier thighs compared with head rails positioned $>0.85 \mathrm{~m}$. More liquid manure (a high manure consistency score) was associated with dirtier thighs $(\mathrm{OR}=1.66)$ compared with a low manure consistency score. Herds with an indoor temperature $>10^{\circ} \mathrm{C}$ were associated with cleaner thighs $(\mathrm{OR}=0.80)$ compared with lower temperatures.
The cleanest cows were found in the temperature zone between 10 and $15^{\circ} \mathrm{C}$ (calculated in a spreadsheet). When indoor temperature was $>15^{\circ} \mathrm{C}$, the dirtiness of thighs increased with increasing temperature. Herds with calm and tame cows (grade 1) were associated with cleaner cows than herds graded 2 for tameness $(\mathrm{OR}=$ 1.24). A 10-percentage-unit increase in $\mathrm{RH}$ resulted in dirtier thighs $\left[\mathrm{OR}=1.32\right.$ calculated as $\left.\left(\mathrm{e}^{0.028 \times 10}\right)\right]$ compared with lower RH. The cluster effects showed an OR $=7.01$ for finding another dirty cow in a herd (score 2 to 4) with dirty cows. Furthermore, the risk of the right thigh being dirty when the left thigh was dirty was OR $=1.99$. No random effect of observer was found in the statistical analyses.

\section{DISCUSSION}

\section{Cow Cleanliness}

In support of previous studies (Schreiner and Ruegg, 2003; Veissier et al., 2004; Breen et al., 2009), the present study showed that the cows were relatively clean on the udder and belly, dirtier on thigh and the rear part of the body, and dirtiest on the legs. Generally, the total cow cleanliness score was surprisingly low, with only $19.7 \%$ scoring more than 10 points, and only $2.0 \%$ with more than 15 points. The udder was cleaner compared with those in other studies (Schreiner and Ruegg, 2003; Veissier et al., 2004; Reneau et al., 2005). This was because of smaller herd sizes with a better opportunity for improved individual cleaning and general 
care. The udder of dairy cows is normally clean because it is cleaned daily in connection with milking (Veissier et al., 2004). The cleanliness score for legs supported results of Schreiner and Ruegg (2003) and Veissier et al. (2004), but was lower than those of Reneau et al. (2005) and Breen et al. (2009). The legs are normally the dirtiest part of the animal, because the cows walk in the manure covering the alley. The cleanliness score for the rear part of the body was lower than that reported by Veissier et al. (2004) and Reneau et al. (2005), whereas the thigh cleanliness score supported those reported in the 2 studies.

\section{Thigh Cleanliness}

The cluster effect of herd $(\mathrm{OR}=7.01)$ indicates that dirty thighs were strongly associated with herd. Herd properties are more important for thigh cleanliness than individual properties. This is in contrast to Schreiner and Ruegg (2003), Veissier et al. (2004), and Reneau et al. (2005), who indicated the effect of herd to be of minor importance. One reason for this discrepancy might be that the smaller herd sizes in this study offered a better opportunity for individual management of the cows. Several housing and management factors influenced thigh cleanliness; thigh cleanliness will be influenced by properties of the lying area. Dirt in the stalls originates from cows defecating when lying in the stall, from cows standing in or beside the stalls, or it is transported on the feet and legs of the cows into the stalls from the alleys; however, no information about the origins of contamination was recorded in present study. Despite the small number of eliminative behaviors occurring in the stall, Tucker et al. (2005) reported that a large proportion of defecations occur while cows are lying down; hence, a better understanding of this behavior may be useful for improving stall design and to keep cows cleaner. An upper head rail positioned between 0.52 and $0.85 \mathrm{~m}$ above the stall base was associated with dirtier thighs. In this context, Veissier et al. (2004) investigated stall design in a field study, and suspected that the head rails had an influence on behavior of cows when standing up, and thereby on cow cleanliness, because they found that an "enclosed" front construction was associated with dirtier cows. This finding indicated that the freestall design should be with fewer rails to allow more space for the cows to lunge forward to attain improved cleanliness. Use of sawdust as bedding was positively associated with thigh cleanliness, whereas the amount of bedding recorded was one of the variables excluded before running the full model. The amount of sawdust used per stall was quite low, 0.6 $\pm 1.2 \mathrm{~L}$ per stall for all herds, but apparently enough to positively influence stall cleanliness.
A high density of cows (a high number of cows per freestall) means more manure per unit of area. One might expect an association with more contaminated animals, which we found, and which supports Veissier et al. (2004). Increased competition for access to the freestalls could force animals to use the alleys for lying. A positive effect of manure viscosity was found, in which drier manure was associated with cleaner thighs, supporting Hughes (2001) and Ward et al. (2002). More liquid manure will splash when cows are moving or defecating in the alleys and it will cover a larger area of the stall surface and the bodies of the animals. A few studies compare the finding that a higher indoor temperature is associated with cleaner thighs and that optimal thigh cleanliness is observed in the temperature range from 10 to $15^{\circ} \mathrm{C}$. Some studies on cow cleanliness in relation to temperature do exist (De Palo et al., 2006); however, these studies are more concerned with heat stress. Increased RH was associated with dirtier thighs, suggesting that excreta are stickier under humid conditions, but no studies confirming this were found. Tame cows were associated with cleaner thighs, suggesting that tame cows feel safer or less stressed, making them defecate less or with a denser consistency. Cow cleanliness is often suggested as an indicator of herdsmanship and management (Veissier et al., 2004). In the present study none of the traditional management factors, such as brushing or cleaning out of the stalls, were on the list of significant factors in the full model. One must keep in mind that other measures could be associated with thigh cleanliness because even traits normally being significant ( $P$-values from 0.001 to 0.05$)$ were excluded because of the method used.

\section{CONCLUSIONS}

Clean thighs were associated with position of upper head rail, number of cows per stall, use of sawdust, manure consistency, indoor climate, and cow tameness. Freestalls with a construction that hinders normal lying, rising, and standing movements, especially with respect to the position of the upper head rail, should be avoided. Furthermore, focus is needed on indoor climate, and other factors that influence manure consistency, to obtain cows with clean thighs.

\section{ACKNOWLEDGMENTS}

The authors thank the participating farmers and technicians for their help during the study. Access to the data was given by the Norwegian Dairy Herd Recording System (Ås, Norway) and the Norwegian Cattle Health Services (Ås, Norway) in agreement number 3/2006. The study was financially supported by grants from the 
Foundation for Research Levy on Agricultural Products (Oslo, Norway), the Research Council of Norway (Oslo, Norway), and Agricultural Agreement Research Fund (Oslo, Norway).

\section{REFERENCES}

Bramley, M. 1962. Kow kubicles. Pages 69-73. Farm Buildings Association, Stowmarket, Suffolk, UK.

Breen, J. E., M. J. Green, and J. Bradley. 2009. Quarter and cow risk factors associated with the occurrence of clinical mastitis in dairy cows in the United Kingdom. J. Dairy Sci. 92:2551-2561.

Carey, V., S. L. Seger, and P. Diggle. 1993. Modeling multivariate binary data with alternating logistic regressions. Biometrika 80:517-526.

De Palo, P., A. Tateo, F. Zezza, M. Corrente, and P. Centoducati. 2006. Influence of freestall flooring on comfort and hygiene of dairy cows during warm climatic conditions. J. Dairy Sci. 89:4583-4595.

Fregonesi, J. A., M. A. G. von Keyserlingk, C. B. Tucker, D. M. Veira, and D. M. Weary. 2009. Neck-rail position in the free stall affects standing behavior and udder and stall cleanliness. J. Dairy Sci. 92:1979-1985.

Fulwider, W. K., T. Grandin, D. J. Garrick, T. E. Engle, W. D. Lamm, N. L. Dalsted, and B. E. Rollin. 2007. Influence of freestall base on tarsal joint lesions and hygiene in dairy cows. J. Dairy Sci. 90:3559-3566.

Gygax, L., R. Siegwart, and B. Wechsler. 2007. Effects of space allowance on the behaviour and cleanliness of finishing bulls kept in pens with fully slatted rubber coated flooring. Appl. Anim. Behav. Sci. 107:1-12.

Herlin, A. H. 1997. Comparison of lying area surfaces for dairy cows by preference, hygiene and lying down behaviour. Swedish J. Agric. Res. 27:189-196.

Hughes, J. W. 2001. A system for assessing cow cleanliness. In Pract. $23: 517-524$.

Hulsen, J. 2005. Cow Signals. Roodbont Publishers, Zutphen, the Netherlands.

Hultgren, J., and C. Bergsten. 2001. Effects of rubber-slatted flooring system on cleanliness and foot health in tied dairy cows. Prev. Vet. Med. 52:75-89.

Kilgour, R. 1975. The open-field test as an assessment of the temperament of dairy cows. Anim. Behav. 23:615-624.
Magnusson, M., A. H. Herlin, and M. Ventorp. 2008. Short communication: Effect of alley floor cleanliness on freestall and udder hygiene. J. Dairy Sci. 91:3927-3930.

Munoz, M. A., G. J. Bennett, C. Ahlström, H. M. Griffiths, Y. H. Schukken, and R. N. Zadoks. 2008. Cleanliness scores as indicator of klebsiella exposure in dairy cows. J. Dairy Sci. 91:3908-3916.

Norring, M., E. Manninen, A. M. de Passillé, J. Rushen, L. Munksgaard, and H. Salonemi. 2008. Effects of sand and straw bedding on the lying behavior, cleanliness, and hoof and hock injuries of dairy cows. J. Dairy Sci. 91:570-576.

Reneau, J. K., A. J. Seykora, B. J. Heins, M. I. Endres, R. J. Farnsworth, and R. F. Bey. 2005. Association between hygiene scores and somatic cell scores in dairy cattle. J. Am. Vet. Med. Assoc. 227:1297-1301.

Schmisseur, W. E., J. L. Albright, C. M. Brown, W. M. Dillon, E. W. Kehrberg, and W. H. M. Morris. 1966. Comparison of freestall to conventional loose housing. J. Dairy Sci. 49:730. (Abstr.)

Schreiner, D. A., and P. L. Ruegg. 2003. Relationship between udder and leg hygiene scores and subclinical mastitis. J. Dairy Sci. 86:3460-3465.

Tucker, C. B., D. M. Weary, and D. Fraser. 2005. Influence of neck-rail placement on freestall preference, use, and cleanliness. J. Dairy Sci. 88:2730-2737.

Veissier, I., J. Capdeville, and E. Delval. 2004. Cubicle housing systems for cattle: Comfort of dairy cows depends on cubicle adjustment. J. Anim. Sci. 82:3321-3337.

Waiblinger, S., C. Menke, and D. W. Fölsch. 2003. Influences on the avoidance and approach behaviour of dairy cows towards humans on 35 farms. Appl. Anim. Behav. Sci. 84:23-39.

Ward, W. R., J. W. Hughes, W. B. Faull, P. J. Cripps, J. P. Sutherland, and J. E. Sutherst. 2002. Observational study of temperature, moisture, $\mathrm{pH}$ and bacteria in straw bedding, and faecal consistency, cleanliness and mastitis in cows in four dairy herds. Vet. Rec. 151:199-206.

Zdanowicz, M., J. A. Shelford, C. B. Tucker, D. M. Weary, and M. A. G. von Keyserlingk. 2004. Bacterial populations on teat ends of dairy cows housed in free stalls and bedded with either sand or sawdust. J. Dairy Sci. 87:1694-1701. 